\title{
Sir David Percival Dalbreck Wilkie, O.B.E., M.D.,
}

\author{
Ch.M., F.R.C.S.
}

SIR DAVID Wilkie was a son of Angus. Fifty-six years ago he was born in Kirriemuir. At the time of his death, although comparatively young in years, he had already established for himself an international reputation as a surgeon, and was recognised as one of the leaders in medicine in this country. A number of factors combined to bring this about: he possessed a personality endowed with an unconscious charm, so that anyone who once came under its sway became thereafter a willing recruit in his service. This charm was enhanced by a voice that when used in private conversation, in the lecture theatre, or through the microphone over the wireless was always a pleasure to listen to, and carried the stamp of simple sincerity and sound conviction.

His school days were spent at the Edinburgh Academy, after which he became a student of medicine of Edinburgh University. He graduated in I904, and although his record was creditable, it did not so far reveal promise of that brilliancy that later years brought forth.

Wilkie took naturally to surgery as his life's work, drawn to it as work where heroic remedies were used that required delicacy of judgment and delicacy of touch to restore the patient to health again.

Professor F. M. Caird and Sir Harold Stiles found in him an apt pupil and set his feet firmly on the ladder of success. The many practical problems revealed at the bedside, in the wards, and in the operating theatre, which dealt with the comfort, the speed of cure, or even the life of the patient that called for a solution, at once raised in Wilkie the devoted spirit of the research scholar, and to find an answer to these he enrolled as a worker in the Royal College of Physicians' Laboratory. The cause of appendicitis was investigated, as also were the prevention and cure of peritonitis, and that deadly disease, acute intestinal obstruction, he studied by experimental research. The brilliancy with which these problems were investigated, the lucid and accurate way in which the results were set forth, at once drew the attention of the medical world to the fact that again in the Edinburgh Medical School another lamp was lit, another star had risen.

It was now but a short step to England, France, and the continent of North America. 
Already a Fellow of the Royal College of Surgeons of Edinburgh, he now became a Fellow of the Royal College of Surgeons of England. He was appointed a corresponding member of the French Academy of Surgery, and on one of his visits to America he was elected an Honorary Fellow of the American College of Surgeons, and delivered the Annual Murphy Oration to the Fellows of that college.

In 1924 he succeeded Alexis Thomson as Professor of Surgery in the University of Edinburgh, when, following his natural inclination, he at once founded the Research Laboratory attached to that department. To these laboratories there were attracted many young research workers from home and abroad.

On shoulders broad and willing, but never very robust, there was now placed a steadily increasing burden: the claims of a systematic chair, the direction of a research department, the duties of a clinical charge, and a most exacting private practice occupied fully his entire working day. To these there were added claims from London, when he was called upon to serve as a member of the Medical Research Council, on the Advisory Board of the Army Medical Staff, and the Scientific Advisory Committee of the British Empire Cancer Campaign. These appointments necessitated frequent journeys to London, and, in addition, he was called upon to address many medical meetings in the provinces.

Perhaps it was the discipline of the navy that Wilkie acquired when serving during the War as a Surgeon Commander in the Royal Naval Volunteer Reserve that led to his ready acceptance of these many calls on his time, or possibly his inability to refuse requests for help that explained his assumption of this staggering load. Under its weight more than once he broke down, but quickly recovered after a short rest, but at last the dread ailment, in the cure of which he had given a life's study, seized him, and after a gallant and courageous effort he finally acknowledged defeat:

"Under the wide and starry sky,

Dig the grave and let me lie.

Glad did I live and gladly die,

And I laid me down with a will.

This be the verse you grave for me:

Here he lies where he longed to be,

Home is the sailor, home from the sea,

And the hunter home from the hill."

He was elected a Fellow of this Society in 1925, and died on August 28, 1938 .

H. W. 